\title{
THE POSSIBILITY OF THE RIGHT TO RELIGION EMERGING AS A JUS COGENS NORM (PART 2)
}

\author{
David Abrahams \\ BJuris LLB LLM LLM \\ Lecturer, Faculty of Law \\ Nelson Mandela Metropolitan University \\ Port Elizabeth \\ Tayla Dye \\ LLB
}

\section{SUMMARY}

This article follows a previous article published in Obiter Vol 2 of 2016. In that article the concept of jus cogens and its role in the international community, together with the nature of the right to religion, were discussed. In Part Two, the seriousness of such human rights violations needs to be appreciated by the international community at large. To this end, the Democratic People's Republic of Korea will serve as a case study, examining the extent of the DPRK's compliance of its obligations vis-à-vis the right to religion. This should ultimately lead to an understanding as to why the right to religion emerging as a jus cogens norm will not solve the problem of enforcement, and even if it could, due to the uncertainty surrounding the formation of jus cogens it is unlikely that other human rights will be added to the list in the near future.

\section{INTRODUCTION}

In Part One ${ }^{1}$ the concept of jus cogens was explored. This was done by looking at the theory and development of jus cogens. The substantive contents and the legal consequences of jus cogens were also briefly considered.

Secondly, the right to freedom of belief, conscience and religion was discussed. This discussion detailed various applicable provisions in international instruments, which for practical purposes shall not be repeated here. $^{2}$ In particular, the right to freedom of religion was analysed by considering various norms and limitations to the right to freedom of religion.

Thirdly, a consideration was given to regional courts, including the European Court of Human Rights, the African Commission and Court on

\footnotetext{
See Abrahams and Dye "The Possibility of the Right to Religion Emerging as a Jus Cogens Norm (Part 1)" 2016 37(2) Obiter 201-227.

2 Abrahams and Dye 2016 37(2) Obiter 215-219.
} 
Human and Peoples' Rights, and the Inter-American Commission and Court on Human Rights, and how these courts interpreted the right to religion. A rich jurisprudence of cases emerged from these courts, none of which conclusively elicits the right to religion as emerging as a jus cogens norm.

In this article, the domestic laws of the DPRK, the extent to which their international obligations have been complied with, and accountability for non-compliance are considered. The DPRK ranks high on the Open Door's World Watch-List for persecuted Christians. ${ }^{3}$ A short discussion on the persecution of practising Christians as a political crime is also undertaken. Lastly, the issue of accountability is discussed in some detail, with particular reference to sessions of the United Nations Human Rights Council and the United Nations General Assembly. The article concludes with the authors' conclusions and outlines recommendations in light of the aforementioned postulations. What follows is a case study of the Democratic People's Republic of Korea.

\section{A CASE STUDY: DEMOCRATIC PEOPLE'S REPUBLIC OF KOREA}

Gross violations of the right to freedom of religion take place world-wide and yet many of these countries are state parties to international instruments which prohibit such violations. ${ }^{4}$ In this section the authors consider how the DPRK has integrated these international standards into its domestic system of law, if at all. Furthermore, the extent to which obligations in accordance with international standards have been complied with in the DPRK will be deliberated. Lastly, the concept of holding the DPRK accountable for violations of human rights shall be considered.

This part further considers how the DPRK has deviated from the international standard of the right to religion, ${ }^{5}$ and what the international community should do in light of this. Various international instruments, domestic laws, the Commission of Inquiry of Human Rights report, The United Nations General Assembly ${ }^{6}$ Universal Periodic Reviews, Amnesty International recommendations, as well as books and journal articles have been considered in order to further this intention. An investigation of the domestic law of the DPRK will follow.

3 Open Doors http://www.opendoorsusa.org/christian-persecution/world-watch-list/ (accessed 2015-11-13).

4 United States of America Department of State Office on International Religious Freedom United States Commission on International Religious Freedom Annual Report 2014 Washington 20145 (hereinafter "USCIRF 2014 Report").

5 See paragraph 3 for a detailed discussion on the right to religion in Abrahams and Dye 2016 37(2) Obiter 215.

6 Hereinafter "UNGA". 


\section{Domestic law of the Democratic People's Republic of Korea}

The DPRK acceded to the ICCPR on 14 September $1981 .{ }^{7}$ Article 2 of the ICCPR states that each state party to the covenant undertakes certain obligations, including ensuring the recognition of rights provided for in the ICCPR, taking necessary steps to adopt legislative or other measures to realize such rights and ensuring the right to an effective remedy for persons whose rights have been violated. ${ }^{8}$ Moreover, Article 40 instructs State parties to submit reports to the relevant committee indicating the measures that have been adopted in the furtherance of the rights recognised in the ICCPR and how persons enjoy such rights. ${ }^{9}$ The DPRK, as a State party to the ICCPR, therefore bears a legal duty not only to recognize the rights as they appear in the ICCPR, but to provide measures whereby such rights may be realised, hold accountable those that do not respect such measures, and report on advances made in this regard. ${ }^{10}$

Article 68 of the Constitution of the Democratic People's Republic of Korea, ${ }^{11}$ as revised in 2012, declares that its citizens have "freedom of religious beliefs", and that enforcement of such right is evident by the approval of construction of religious buildings, as well as approval of the holding of religious ceremonies. It does, however, state that religion shall not be used as a guise for attracting foreign forces or damaging the State and social order ${ }^{12}$ It is therein that the right to religion is most limited, since any association with an outside group, such as an American missionary association, can be construed as "attracting foreign forces" or "damaging the [s]tate and social order". ${ }^{13}$

It must be noted that the DPRK Constitution is not supreme and the "Supreme People's Assembly is the highest organ of [s]tate power" in the DPRK. ${ }^{14}$ In this system of parliamentary sovereignty, any law which is contrary to the ideals of the constitution would not necessarily be struck down. It is thus the responsibility of the legislature to comply with the obligations of the DPRK as provided for the in the ICCPR.

It would seem that no domestic law exists whereby such rights are protected, nor is there any legislation or provision providing consequences for the infringement of such right outlined in the constitution or in the ICCPR.

7 United Nations Treaty Collection https://treaties.un.org/Pages/ViewDetails.aspx?src= TREATY\&mtdsg_no=IV-4\&chapter=4\&lang=en (accessed 2014-09-28).

8 Article 2 of the UN General Assembly International Covenant on Civil and Political Rights 16 December 1966 United Nations Treaty Series Vol 999171 http://www.refworld.org/docid/ 3ae6b3aa0.html (accessed 2015-11-15) (hereinafter "ICCPR").

9 Article 40 of the ICCPR.

10 Article 2 and Article 40 of the ICCPR.

11 Socialist Constitution of the Democratic People's Republic of Korea 5 September 1998 http://www.refworld.org/docid/3ae6b56d0.html (accessed 2015-11-13) - (hereinafter "DPRK Constitution").

12 Article 68 of the DPRK Constitution.

13 United States of America Department of State Office on International Religious Freedom United States Commission on International Religious Freedom Annual Report 2013, Washington, April 2013110 (hereinafter "USCIRF 2013 Report").

14 Article 87 of the DPRK Constitution. 
What does, however, exist is the Criminal Code. ${ }^{15}$ The report of the Commission of Inquiry on Human Rights in the Democratic People's Republic of Korea submits that the way in which many of the crimes are worded makes it highly possible that the exercise - as opposed to infringement - of human rights can be prosecuted as a crime. ${ }^{16}$

Chapter 3 of the DPRK's Criminal Code describes a list of "Crimes against the State and the Nation" which are broadly defined. Prominent in each offence is the term "with an anti-[s]tate purpose". ${ }^{17}$ Since a "prominent state purpose", as shall be discussed, is the reverence of the ruling Kim family, reverence of any other being or notion, particularly God, can be seen as an "anti-state purpose", for which any of the "Crimes against the State and the Nation" could fit. The Commission points out that practising one's religion, like Christianity, is not specifically mentioned as a crime, but is deemed to be a political crime.

Chapter 6 of the DPRK's Criminal Code outlines "Crimes of Impairing Socialist Culture", whereby Article 194 deems it to be a criminal offence to watch or listen to music, dance, read books, watch video recordings or electronic media, where such things "reflect decadent, carnal or foul contents or who performs such acts", and such a person may be punished by way of forced labour. ${ }^{19}$ It is submitted that the broad construction of such a provision could almost certainly lead to things such as bibles, religious tracts, worship music, and anything applicable to what a person may believe and would want to explore deeper in their belief, can be deemed to be "decadent, carnal or foul". In light of the abovementioned, the extent to which DPRK's obligations in terms of the ICCPR have been complied with will be considered.

\section{Extent to which obligations have been complied with}

\section{The façade of the right to freedom of religion}

As has already been alluded to, the DPRK has done very little to comply with their obligations in terms of the ICCPR. It would seem that the DPRK has a dual policy whereby it appears to the outside world that there is a guarantee

15 The Criminal Law of the People's Republic of Korea 2009 translated by Citizens' Alliance for North Korean Human Rights https://eng.nkhumanrights.or.kr:444/board/bbs_view.php?no =4\&board_table=bbs_literature\&page $=1 \&$ word=\&searchltem $=\&$ cate_id $=$ (accessed 201410-4) (hereinafter "Criminal Code").

16 UN Human Rights Council Report of the Detailed findings of the Commission of Inquiry on Human Rights in the Democratic People's Republic of Korea 7 February 2014 A/HRC/25/CRP.1 http://www.refworld.org/docid/530314234.html (accessed 2015-11-13) par 122 (hereinafter "the Commission" or "the Commission Report"). Chapter 3 of the Criminal Code.

18 The Commission Report par 254.

19 Article 194 of the Criminal Code. 
of religious freedom. However, the policy implementation on an internal level is one of suppression of religion. ${ }^{20}$

Although the DPRK claims, "Every citizen in the DPRK enjoys full freedom of and right to religion", and "[t]he Korean Federation of Buddhists, the Korean Federation of Christians and other religious groups are a proud part of political parties and public institutions", the reality of the situation is somewhat different. ${ }^{21}$ It is reported that church buildings that do exist in the country primarily operate as tourist attractions, or instruments to create the perception that persons can practise their right to religion. ${ }^{22}$ The churches or Buddhist temples that do exist are controlled by the State, as are the clergymen or monks therein. Despite the opportunity to study further by way of a theological degree at the Kim II-sung University, such persons are carefully selected and are ultimately the State-controlled religious leaders that are placed back into leading the State-controlled religious entities. ${ }^{23}$ Alternatively, graduates of such programmes are used to identify persons who practise "clandestine religious activity." ${ }^{24}$

\section{Institutionalization of the personality cult}

The belief structure in the DPRK is such that the revering of the ruling Kim family is a pseudo-religion. ${ }^{25}$ Other sources describe it as a "cult of personality ... extended to Kim Jong-un", the leader of the DPRK ${ }^{26}$ What is required of the populace is "unwavering obedience" such that no political aberration therefrom is acceptable. ${ }^{27}$ When Kim-Jong-il, father to current leader Kim Jong-un, came to power in 1974, he introduced the "Ten Principles in Establishing Party's Monolithic Ideological System". The principles state that everyone owes all loyalty and absolute obedience to their leader and that society must adhere strictly to the one-ideology system. ${ }^{28}$ Children are taught from a young age to venerate the Kim family and personalize the State ideology into their own being. ${ }^{29}$

Throughout the life of a person living in the DPRK, that person is bombarded from all angles with propaganda. Indoctrination of the nation takes place in all spheres of life, from schooling to public rallies to sporting events. The State ideology is to be assimilated into oneself in every possible way. ${ }^{30}$ Article 18 of the ICCPR not only provides for freedom of religion, but

20 Yeo-sang and Sun-young 2009 White Paper on Religious Freedom in North Korea (2009) 27-28.

21 Democratic People's Republic of Korea Official webpage of the DPR of Korea "Religion" http://korea-dpr.com/religion.html (accessed 2015-11-13).

22 Cole "America's Role in Preventing Anti-Christian Persecution" 2013221 Michigan State International LR 455474.

3 The Commission Report par 250-251.

24 USCIRF 2013 Report 110-111.

USCIRF 2014 Report 71.

USCIRF 2013 Report 4.

The Commission Report par 241

The Commission Report par 131

The Commission Report par 196.

The Commission Report par 165-196. 
also for freedom of conscience and belief. ${ }^{31}$ It is submitted that such practices are in gross violation of this aspect of the right, since one is forced to think and act in a particular way, and personalize the doctrine in such a way that it impinges on one's freedom of thought. Furthermore, this personality cult seems to create justification for limitation of one's right to freedom of religion in terms of Article 68 of the DPRK Constitution, since believing in a higher power other than the Kim family could be construed as "damage to the [s]tate and social order." ${ }^{32}$ Private religious activity that the Government has not ordained is construed as a security threat to the social order. $^{33}$

\section{Religious persecution}

The DPRK is ranked number one on the Open Door's World Watch List for persecuted Christians. ${ }^{34}$ In 2002 , only 0.16 per cent of the population are "religious adherents" compared to the 24 per cent of $1950 .{ }^{35}$ When citizens were asked by the Citizen's Alliance for North Korean Human Rights if people would be punished for engaging in religious activity, a meagre 0.9 per cent said that they would not. The only possible conclusion to be drawn therefrom is that the populace of the DPRK know that should they practice their religion, they will be punished. ${ }^{36}$ Jae-Chun Won describes the four stages of oppression which ultimately culminated in the DPRK the world knows today. ${ }^{37}$ The fourth and final phase is described as the era of Juche, where there is an appearance of religion-friendly policy, but the reality paints the picture of anti-religion propaganda, public executions, and imprisonment in kyohwaso, as well as political penal concentration camps. ${ }^{38}$

It must be noted that, even though all religions and freedom of belief or conscience is violated, it is particularly true with Christianity. The Commission proposes three main reasons for why Christians are singled out in this regard. Firstly, they "pose a threat to the stability of society", since they do not revere the leaders of the country as they ought to, nor do they personally subscribe to the ideology that the DPRK authorities promote their ideology. Secondly, since Christianity is the religion of enemy states, such as the United States of America and South Korea, Christians are deemed to be spies. Thirdly, they are blamed for the fall of communism in Eastern Europe, as well as in the Soviet Union due to the strong resistance offered by the Roman Catholic Church in countries like Poland.

The Database Centre for North Korean Human Rights reports that, should a person be caught possessing religious materials, or participating in

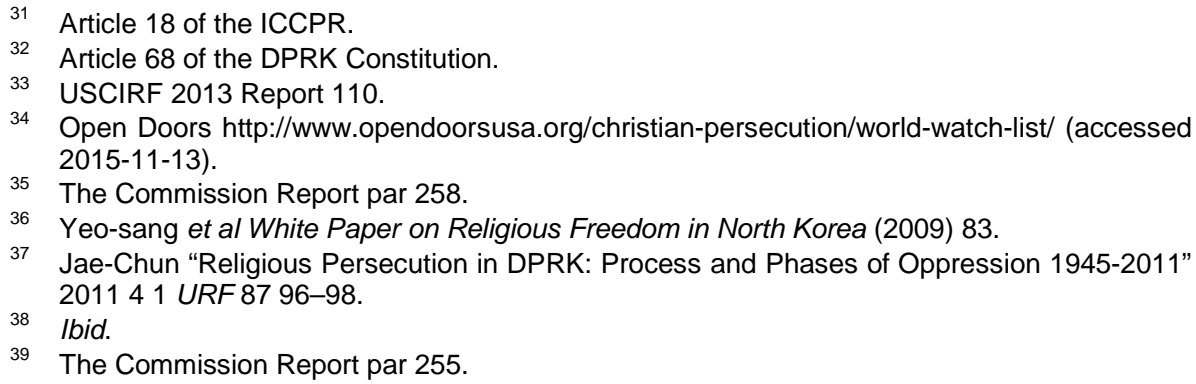


unauthorized meetings, or attempting to reach out to religious groups outside of the country, they will be punished. The remaining society is enticed to report such activity to the authorities, further dividing the nation by earning reward. ${ }^{40}$

\section{Practising Christianity as a political crime}

Kim-II-sung, grandfather to current leader, Kim Jong-un, has been quoted as saying that "religious people should die to cure their habit." ${ }^{41}$ The DPRK State Security Department is instructed to seek out Christians intentionally and are praised when they expose covert religious activity. ${ }^{42}$ Agents are trained in religion so as to infiltrate the underground groups. Once Christians are apprehended, they are subjected to a drawn-out interrogation process and are tortured to give up information pertaining to other believers.

It is reported that imprisonment of religious believers is common practice and it is estimated that 150,000 to 200,000 prisoners reside in political prison camps, many of which are there because of their religious beliefs. Approximately 6,000 Christians are imprisoned in a political prison in the northern part of the country. The USCIRF 2013 Report states that, among the other prisoners, Christian prisoners are treated the worst and are given the more dangerous tasks to do and are often violated until they renounce their faith. ${ }^{44}$

It is at this point that political prison camps must be distinguished from the penal labour camps used for ordinary offenders who have contravened the DPRK Criminal Code. DPRK Government denies the existence of political prison camps, kwanliso, from which the victims never leave once incarcerated. The Commission has found that an extensive system of political prison camps exist. The idea is to remove such members from society altogether because they pose some type of threat to the socialist system. ${ }^{45}$ What is to be done to curb such gross human-rights violations? The steps taken by the international community will now be explored.

\section{Accountability}

\section{Commission of Inquiry of Human Rights Report, February 2014}

In December 2009, the Working Group on the Universal Periodic Review had their thirteenth session, where much focus was given to the DPRK. Various countries expressed their concerns regarding a number of human

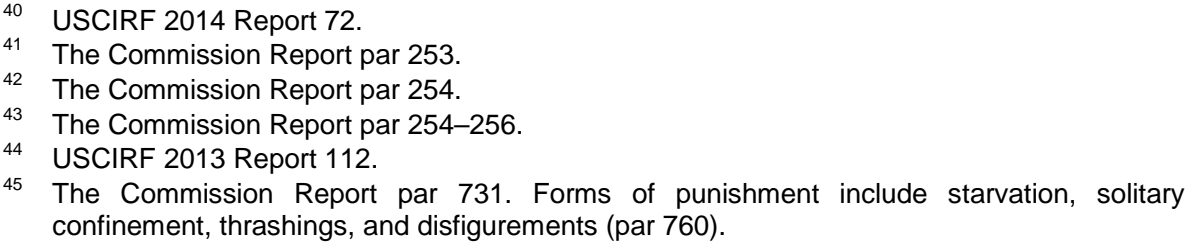


rights violations in the DPRK, of which violations of the right to religion were raised. ${ }^{46}$

On 7 February 2014, the Commission of Inquiry of Human Rights released a report on its detailed findings after extensive investigation into the DPRK. The Commission collected its data by way of first-hand testimonies through public hearings of victims and witnesses who had escaped the DPRK. ${ }^{47}$ They also conducted confidential interviews, accepted written submissions, reviewed other written material, engaged with states who have direct contact with the DPRK, and cooperated with other humanitarian entities. ${ }^{48}$

The Commission found that crimes against humanity were committed. It outlines the subjects of such crimes against humanity as being persons detained in political prison camps and other prison camps: those who attempt to escape the country; devotees of the Christian faith, and persons considered to be insurgent influences. ${ }^{49}$ As stated by the Commission:

"In the DPRK, international crimes appear to be intrinsic to the fabric of the state. The system is pitiless, pervasive and with few equivalents in modern international affairs. The fact that such enormous crimes could be going on for such a long time is an affront to universal human rights. These crimes must cease immediately. It is the duty of the DPRK and, failing that, the international community to ensure that this is done without delay."

The report continues to detail the various state parties which would be held criminally liable for their crimes against humanity, and concludes that all of the sectors of the Workers' Party of Korea are implicated in humanrights violations and crimes against humanity. ${ }^{51}$ Prohibition of crimes against humanity is considered to be a peremptory norm, and as such is binding on the entire international community as part of customary international law, in spite of the fact that DPRK is not a state party to the Rome Statute of the International Criminal Court. ${ }^{52}$ The Commission authorized further investigations in order to guarantee accountability for the crimes committed. ${ }^{53}$

46 UN Human Rights Council, Report of the Working Group on the Universal Periodic Review on the Democratic People's Republic of Korea 4 January 2010 A/HRC/13/13 http://www.refworld.org/docid/4bdfdab22.html (accessed 2015-11-13). The Ambassador and Permanent Representative of the DPRK responded to the Human Rights Council by stating that they reject the references made to the situation in the DPRK "which were based on information fabricated and distorted ... to eliminate the Democratic People's Republic of Korea." The DPRK rejected the references made to it (UN GA, Letter dated 11 March 2010 from the Permanent Representative of the Democratic People's Republic of Korea to the United Nations Office at Geneva addressed to the President of the Human Rights Council 15 March 2010 A/HRC/13/G/18 http://www.un.org/ga/search/view_doc.asp?symbol=A\%2

48 The Commission Report par 30-46.

49 The Commission Report par 1160-1161.

50 The Commission Report par 1164.

51 The Commission Report par 1193-1194.

52 The Commission Report par 1195.

53 The Commission Report par 1196. 
The Commission wrote a letter addressed to Kim Jong-un, the leader of the DPRK, and divulged the findings of their report on 20 January 2014. The Commission also pressed that he take the needed steps to avert further crimes, and divulge crimes already committed to the relevant authorities for further investigation and prosecution. ${ }^{54}$ Ordinarily, the DPRK would be required to investigate and prosecute crimes against humanity, but since the very institutions that would ordinarily perform such a task are the perpetrators, this would be inappropriate. ${ }^{55}$ It is therefore inescapable that the international community has to ensure that justice is done. ${ }^{56}$

Thus far, peaceful steps taken have been insufficient. The DPRK had simply refused to cooperate, and accused the UNGA and Human Rights Council of "infringing on the sovereignty of the DPRK". 57 The Commission notes that the fact that the DPRK has gotten away with running the country in such a way, as a state member of the United Nations, seriously calls into question the adequacy of the capabilities of the international community. ${ }^{58}$

The Commission makes a number of recommendations of what the international community should do. ${ }^{59}$ Firstly, the matter should be referred to the International Criminal Court $^{60}$ by the UNSC. Secondly, sanctions against those responsible for the crimes should be adopted, but not sanctions against the population or the economy as a whole. Thirdly, the UNGA and the Human Rights Commission should specifically monitor the situation and establish reporting mechanisms in this regard. ${ }^{61}$ In addition to recommendations made to the international community, the Commission also outlined what the DPRK should do. ${ }^{62}$

\footnotetext{
The Commission Report par 1198.

The Commission Report par 1199.

The Commission Report par 1200.

The Commission Report par 1208.

The Commission Report par 1217.

59 Such submissions are supported by Amnesty International, who recommended that the Human Rights Council call on all United Nations affiliates to implement the Commission's recommendations; continue to investigate the matter alongside the Commission; and request that the Security-General refer the report to the Commission of the UNSC (Amnesty International Inter-active Dialogue with the Commission of Inquiry on human rights in the Democratic People's Republic of Korea ASA 24/004/2014 17 March 2014 2).

Hereinafter "ICC".

61 The Commission Report par 1225.

62 Such suggestions include the DPRK reforming the politics and institutions of the country by creating a system of checks and balances on the leading party, the DPRK admitting to the human-rights violations and prison camps and allowing humanitarian organizations access to such camps, dismantling such prison camps, modifying the Criminal Code and Code of Criminal Procedure to exclude "anti-state" and "anti-people" crimes, and allowing Christians and other religious believers to exercise their religion freely without fear of persecution (The Commission Report, par 1220).
} 


\section{Human Rights Council}

\section{(i) Twenty-seventh session, July 2014}

The Working Group on the Universal Periodic Review evaluation of the DPRK was held on 1 May 2014. ${ }^{63}$ Surprisingly, the DPRK responded on 12 September 2014, and undertook to accept certain recommendations, take others under advisement, and reject certain recommendations "on the ground that they seriously distorted the reality of and slandered the country, driven by sinister political motivation."64

The following recommendations were accepted or supported by the DPRK and relate to the right to freedom of religion. Firstly, Israel's recommendation that the DPRK "allow all religious believers to exercise their religion independently" was accepted. ${ }^{65}$ Secondly, that the DPRK "[g]uarantee freedom of thought, conscience and religion to all individuals by ensuring the basic rights to freedom of assembly and association" was also accepted. ${ }^{66}$

The following recommendations were noted by the DPRK. Firstly, the Russian Federation's recommendation that the DRPK "reform legislation in the area of the rights of freedom of conscience and belief", was noted. ${ }^{67}$ Secondly, that the DPRK "enhance the promotion and protection of the right to freedom of thought, conscience and religion, including the right to manifest such individually or in community with others in public or private, in worship, observance, practice and teaching, in line with Article 18 of the ICCPR", was noted. ${ }^{68}$

The DPRK refused to adopt the following recommendations which relate to the right to freedom of religion. Firstly, the DPRK refused to "disclose detailed data on the use of the death penalty and the modalities of execution." ${ }^{69}$ It is submitted that this refusal is problematic in that the execution of religious believers can continue, but the world will not know what they have been executed for. Secondly, the DPRK refuse to "end the practice of arbitrary, public and private execution." ${ }^{70}$ This refusal ties in with religious believers being arbitrarily executed, and as previously mentioned, is deeply concerning. Thirdly, the DPRK refused to "make a list of persons in detention, provide access to the International Red Cross to prisons and

63 UN Human Rights Council Report of the Working Group on the Universal Periodic Review: Democratic People's Republic of Korea 2 July 2014 A/HRC/27/10 http://www. refworld.org/docid/53eb231d4.html (accessed 2015-11-13) par 1 (hereinafter "UN HRC July Review").

64 UN Human Rights Council Report of the Working Group on the Universal Periodic Review: Democratic People's Republic of Korea, Views on conclusions and/or recommendations, voluntary commitments and replies presented by the state under review 12 September 2014 A/HRC/27/10/Add.1 http://www.un.org/ga/search/view doc.asp?symbol=A\%2FHRC\%2F 27\%2F10\%2FAdd.1\&Submit=Search\&Lang=E (accessed 2015-11-13), par 3-6.

65 UN HRC July Review par 124.126.

66 UN HRC July Review par 124.128.

7 UN HRC July Review par 124.127.

8 UN HRC July Review par 124.129

69 UN HRC July Review par 124.91.

70 UN HRC July Review par 124.93. 
review all cases of arbitrary arrest or confessions under torture, considering reparation for victims." ${ }^{71}$ Religious believers who have been tortured, arrested and are suffering in the political prison camps will, therefore, not be divulged to the public, nor will they be provided aid or reparation. Fourthly, the DPRK refused to "counter allegations of torture and illtreatment in prison facilities, [and] allow ... international observers to have immediate, full and genuine access to all detention facilities to ensure proper treatment of prisoners." ${ }^{72}$ This leaves one with the feeling that persons will still be arbitrarily arrested and will continue to be tortured and mistreated in the various prison facilities.

Whether the DPRK in fact follows through on the recommendations that it has adopted is yet to be seen. Regardless of this, there needs to be accountability for the human-rights violations already committed.

\section{(ii) Twenty-eighth session, March 2015}

The Special Rapporteur on the situation of human rights in the DPRK ${ }^{73}$ submitted a report to the Human Rights Council. It noted that the Commission's report on the gross human rights violations in the DPRK revealed the truth of the situation that has been ongoing for decades. ${ }^{74}$ It went on further to report that there has been no change in the human rights situation since then. It acknowledged that at first it seemed there would be cooperation from the DPRK in the form of meeting and invitations to visit the country, but such gestures bore no substance.

It called upon the Human Rights Council to reiterate its condemnation of human rights violations; protect people from crimes against humanity, and to press the DPRK to invite the SR into the country. ${ }^{9}$ It called upon the DPRK to stop its human-rights violations; reopen communication with those involved such as the SR and the Office of the United Nations High Commissioner for Human Rights, and to cooperate with the United Nations human-rights mechanisms. ${ }^{7}$

\section{United Nations General Assembly}

$$
\text { Sixty-ninth session, January } 2015
$$

On 18 December 2014 the UNGA adopted a resolution regarding the situation in DPRK. The UNGA condemned the gross human rights violations taking place in the DPRK. ${ }^{78}$ It expressed concern at "[t]he

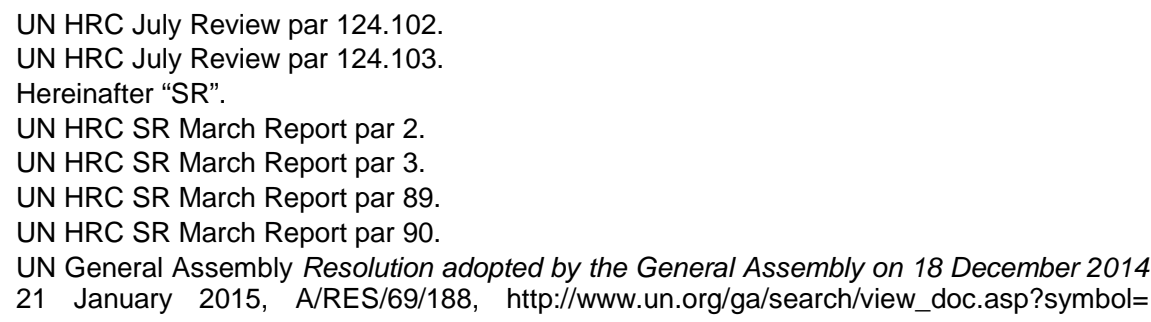


persistence of continuing reports of violations of human rights" and referred specifically to:

"All-pervasive and severe restrictions on the freedom of thought, conscience, religion or belief, opinion and expression, peaceful assembly and association, the right to privacy and equal access to information, by such means as the persecution, torture and imprisonment of individuals exercising their freedom of opinion and expression, religion or belief, and their families, and the right of everyone to take part in the conduct of public affairs, directly or through freely chosen representatives, of his or her country".

It also expressed concern at the DPRK's refusal to recognize the mandate of the SR, as well as its refusal to cooperate. ${ }^{80}$ The DPRK's refusal to acknowledge the human rights violations in the country and their lack of implementation of any recommendations were also noted. ${ }^{81}$ Moreover, the DPRK have not prosecuted any person responsible for the perpetration of crimes against humanity. ${ }^{82}$

Accordingly, the resolution was passed to submit the report of the Commission to the UNSC. It was suggested that the UNSC consider referring the situation to the ICC and deliberate sanctions against specific perpetrators. ${ }^{83}$ On 22 December 2014 the UNSC held its first meeting to address the matter. ${ }^{84}$

\section{(ii) Seventieth session, September 2015}

The SR submitted a report to the UNGA. It noted that in March and June 2015 it requested meetings with the DPRK delegates, but such requests were declined. ${ }^{85}$ The recommendations made by the SR were much the same as their recommendations made in March $2015 .{ }^{86}$ Something more drastic needs to take place in order to hold DPRK to account. Action taken by the UNSC is awaited with anticipation.

A\%2FRES\%2F69\%2F188\&Submit=Search\&Lang=E (accessed 2015-11-13) par 1 (hereinafter "UNGA December Resolution").

79 UNGA December Resolution par 2(a) (v).

UNGA December Resolution par 2(b).

UNGA December Resolution par 2(c).

UNGA December Resolution par 2(d).

UNGA December Resolution par 8.

34 UN Human Rights Council Report of the Special Rapporteur on the situation of human rights in the Democratic People's Republic of Korea 18 March 2015 A/HRC/28/71 http://www.refworld.org/docid/550fefe14.html (accessed 2015-11-13) par 14 - (hereinafter "UN HRC SR March Report").

85 UNGA Situation of human rights in the Democratic People's Republic of Korea: Note by the Secretary General 8 September 2015 A/70/362 http://www.un.org/ga/search/view_doc. asp?symbol=A\%2F70\%2F362\&Submit=Search\&Lang=E (accessed 2015-11-13) par 3 (hereinafter "UNGA September Note").

86 UNGA September Note par 80-81; see also UN General Assembly, Situation of human rights in the Democratic People's Republic of Korea : report of the Secretary-General 2015 25 September 2015 A/70/393 http://www.refworld.org/docid/56288f154.html (accessed 2015-11-13); and UN Human Rights Council, Situation of human rights in the Democratic People's Republic of Korea : resolution adopted by the Human Rights Council 8 April 2015 A/HRC/RES/28/22, http://www.refworld.org/docid/558abbc24.html (accessed 2015-11-13). 


\section{CONCLUSION AND RECOMMENDATIONS}

\section{Conclusion}

The investigation into the DPRK considered how the DPRK had failed to integrate international standards relating to the right to religion into their domestic law. Furthermore, it considered the extent to which obligations in accordance with international standards had not been complied with. Lastly, the concept of holding the DPRK accountable for violation of human rights was considered, together with the steps that the international community had taken to solve the problem. Recommendations will now be made in order to answer the question as to whether it is possible for the right to religion to emerge as a jus cogens norm.

\section{Recommendations}

The question originally posed was whether it is possible for the right to religion to emerge as a jus cogens norm. A corollary issue must be whether this is desirable. Only if it is desirable should the possibility thereof be explored.

One of advantages of jus cogens is that such norms can apply despite the lack of State consent. However, to use the World Watch-list on persecuted Christians as an example the following becomes evident. There are eight countries on the list that have not signed nor ratified the ICCPR. ${ }^{87}$ Ironically, the top eleven most severely-ranked countries, those who have been identified as perpetuating "extreme persecution", have all ratified the ICCPR. ${ }^{88}$ Would forcing those eight countries who have not ratified the ICCPR to observe the right to religion achieve anything, since they are not the worst offenders in terms of the violation of the right to religion? Obviously this list only considers countries in which the right to be Christian has been violated, but it still serves its purpose as an illustration. ${ }^{89}$

Moore phrases this point succinctly:

"Sadly, the assumption of compliance may be farthest from the truth in the realm of international human rights. Despite the dramatic increase in the number of human-rights instruments since World War II, noncompliance remains prevalent."

Furthermore, could emphasizing the importance of the right to religion by having it emerge as a jus cogens have the opposite of the intended effect?

87 In descending order of ranking according to severity of persecution these countries are: Saudi Arabia; Qatar; Myanmar; Brunei Darussalam; Bhutan; Malaysia; Oman; and United Arab Emirates.

88 In descending order of ranking according to severity of persecution these countries are: DPRK; Somalia; Iraq; Syria; Afghanistan; Sudan; Iran; Pakistan; Eritrea; Nigeria; Maldives.

89 Open Doors https://www.opendoorsusa.org/christian-persecution/world-watch-list/ (accessed 2015-11-13); and United Nations Human Rights Office of the High Commissioner for Human Rights "Status of Ratification Interactive Dashboard" (25 November 2015) http://indicators.ohchr.org/ (accessed 2015-11-28).

90 Moore "A Signalling Theory of Human Rights Compliance" 200397 Northwestern University LR 879. 
Obviously the intent is greater protection for the right to religion, but this cannot be at the sacrifice of other human rights. Witte and Green point out that, while there has been greater recognition for human rights on a global scale, such recognition has coincided with an increase in religious conflict. They use the example of Rwanda and Sudan wherein religious extremism is accompanied by "death ... of rival religious believers, as well as persecution, false imprisonment, forced starvation, and savage abuses". They mention Islamic terrorists and the harm done by them too. ${ }^{91}$ Instead of other jus cogens, such as the right to be free from torture or the rights against genocide trumping the right to religion, such rights would be on equal footing and a balance would need to be struck. This is not a desirable position to be in. In addition thereto, the right to religion would trump other rights, such as the right to freedom of expression since the latter is not a jus cogens. All sorts of conduct inconsistent with other human rights that are not jus cogens would become acceptable, technically, in the name of "religion". Another example hereof is the right to gender equality. As pointed out by Bennoune, "international human-rights law offers minimal guidance on the practicalities of sorting out conflicts that arise between these rights to sex equality and freedom of religion." ${ }^{92}$

Another important aspect worth noting is that where there have been violations of human rights in the name of religion or lack thereof, such violations will usually be in contravention of other jus cogens, such as the right to be free from torture or genocide. The situation in the DPRK is a perfect example of this. The Commission did not only take the DPRK to task on their violations of the right to religion in contravention of their obligations in terms of the ICCPR, but also challenged them on their violations of jus cogens. Either way, it did not alter the enforcement procedure of the UN.

Now that the undesirability has been discussed, the possibility of the right to religion emerging as a jus cogens must be considered. Practically, how does something become a jus cogens? The technical requirements for formation of jus cogens has been considered already, but this does not clarify a step-by-step process whereby these norms arise. ${ }^{93}$ Academics do not agree on how jus cogens attained its status. ${ }^{94}$ How then can the right to religion emerge as a jus cogens norm? No other norm has attained jus cogens status since the initial introduction of the concept in the VCLT. Therefore, it is proposed that it is unlikely that the right to religion will attain the status of a jus cogens. Furthermore, even in the unlikely event that this did happen, the practical effect thereof would be minimal. It would not change the enforcement issues that the international community face. Taken further, it could also have the effect of harming the practice of other human rights more than helping those whose right to religion is currently being violated. The possibility of the right to religion emerging as a jus cogens norm is therefore slim.

91 Witte and Green "Religious Freedom, Democracy, and International Human Rights" 2009 Emory International LR 586.

92 Bennoune 2007 Columbia Journal of Transnational Law 404.

93 See earlier discussion on the requirements for formation of jus cogens. See paragraph 222 in Abrahams and Dye 2016 37(2) Obiter 205.

94 See earlier discussion on how jus cogens attained its status. See paragraph 223 in Abrahams and Dye 2016 37(2) Obiter 206. 